\title{
Disentangling the effects of water chemistry and substratum structure on moss-dwelling unicellular and multicellular micro-organisms in spring-fens
}

\author{
Petra HÁJKOVÁ, Jindřiška BOJKOVÁ*, Markéta FRÁNKOVÁ(1), Věra OPRAVILOVÁ, Michal HÁJEK, \\ Kateřina KINTROVÁ and Michal HORSÁK \\ Department of Botany and Zoology, Masaryk University, Kotlářská 2, CZ 61137 Brno, Czech Republic \\ ${ }^{1)}$ Department of Vegetation Ecology Brno, Institute of Botany, Academy of Sciences of the Czech Republic, Pořící $3 b$, CZ 60300 \\ Brno, Czech Republic \\ *e-mail corresponding author: bojkova@centrum.cz
}

\begin{abstract}
Water chemistry is known to be one of the most important factors controlling species composition of many macro-organisms in wetlands. It is unclear to what extent micro-organisms respond to water chemistry as compared to chemistry-mediated substratum structure. We explored how the assemblages of different groups of micro-organisms in bryophyte tufts of spring-fens were determined by water chemistry and substratum structure. The aim was to compare unicellular autotrophic diatoms, unicellular heterotrophic testate amoebae and multicellular heterotrophic monogonont rotifers. Assemblages of all three groups showed a strong compositional gradient correlated with water $\mathrm{pH}$ and conductivity, calcium concentration and dominance of Sphagnum. While a second strong gradient in species composition of diatoms and testate amoebae was explained by factors such as substratum structure and water content, that of rotifers remained unexplained. Unlike the other two groups, testate amoeba assemblages were significantly determined by phosphates. Nitrates and iron were important species composition determinants for diatoms. Rotifers differed from the other groups in that they did not respond significantly to silica, iron or nutrients. When variation caused by substratum characteristics and water chemistry were partitioned out, testate amoebae were controlled more by substratum, while rotifers and diatoms were controlled more by water chemistry. Variation explained by individual effects of substratum or water chemistry, as compared to shared effects, was much lower for rotifers than for testate amoebae and diatoms. Our results show that, in semi-terrestrial ecosystems, $\mathrm{pH}$ and calcium concentrations are generally the main drivers of variation in species composition of unicellular and multicellular microorganisms, mirroring well described patterns for macro-organisms, providing support for general ecological hypotheses. Other water chemistry variables differed between shell-forming and other organisms, and between autotrophic and heterotrophic organisms. Even though water chemistry variables controlled the structure of the bryophyte tufts that acted as substratum for the micro-organisms, both water chemistry and bryophyte structure effects were independently significant for diatoms and testate amoebae. On the other hand, no effects of either substratum characteristics or water chemistry were found for rotifers. This was because their species composition is not influenced by chemical factors, apart from pH and calcium, which both strongly influence the occurrence of Sphagnum.
\end{abstract}

Key words: bryophytes, diatoms, mineral-richness gradient, monogonont rotifers, testate amoebae, variation partitioning

\section{INTRODUCTION}

Water chemistry is known to be one of the most important factors controlling species composition and richness of many wetland macro-organisms (Vitt 2000; Hájek et al. 2002; Horsák \& Hájek 2003; Tahvanainen 2004; Horsák 2006). Less information is available for micro-organisms, which are key organisms in wetland ecosystem functioning, especially peatlands, responding quickly to environmental changes (Gilbert et al. 1998a). Ecologists tend to postulate general concepts (e.g., ecological niches and gradients) on the basis of vegetation or larger animals only, despite uncertainty over whether micro-organisms, like macro-organisms, respond directly to water chemistry, or whether substratum structure is more important. Substratum type has been reported as an important factor controlling species composition of some micro-organismal assemblages (Cox 1988; Rothfritz et al. 1997; Dugan 2001; Cantonati \&
Spitale 2009). Because of their ability to absorb and retain large quantities of water, thus protecting organisms that live within them against climatic changes (Strong 1967; Corbet 1973), bryophytes are one of the most appropriate substrata for many groups of microand meio-organisms (Suren 1992; Linhart et al. 2002; Bertrand et al. 2004; Vincke et al. 2006). Although some authors regard bryophytes as neutral substrata that do not influence micro-organismal assemblages (cf. Bertrand et al. 2004 for diatoms), other studies suggest some relationships between the composition of bryophyte tufts and microbial assemblages (Poulíčková et al. 2004 for diatoms, Opelt et al. 2007 for bacteria, Lamentowicz et al. 2010 for testate amoebae). Different bryophyte species have different abilities to retain water in their cells and, consequently, provide different moisture conditions for organisms inhabiting them. Sphagnum is unique in having large dead cells (hyalocytes) that are specialised for water retention, and hosts 
diverse microflora and microfauna (Hingley 1993). Moisture intensity has therefore been reported as another important environmental factor controlling species composition of micro-organismal communities (De Graaf 1956; Ohtani 1986; Van de Vijver et al. 2003; Poulíčková et al. 2004; Lamentowicz et al. 2010). Apart from moisture, bryophyte chemistry can also influence autotrophic primary producers and, consequently, heterotrophic micro-organisms, such as testate amoebae (Mitchell et al. 2004).

Micro-organisms are characterised by small body size, high dispersal potential, large population sizes, ability to enter dormancy, and rapid reaction to changing environment (Cáceres 1997; Bohonak \& Jenkins 2003, Korhonen et al. 2010). Due to these characteristics, the proportions of ubiquitous and cosmopolitan species are significantly higher in micro- than macroorganisms (Fontaneto et al. 2008; Segers \& De Smet 2008). It is not clear whether the presumed dispersal capability of micro-organisms causes their tighter relationships to environmental factors. It is generally believed that short generation time and wide distribution of micro-organism species makes them good bioindicators (Mitchell et al. 2008). On the other hand, the significance of mass effects in high-dispersal systems $(\mathrm{Ng}$ et al. 2009) may result in a weaker response of species composition to ecological gradients. Particular taxonomic groups of micro-organisms differ in body structure (uni- versus multicellular), position in the trophic chain (auto- versus heterotrophy), ability to move and/or become dormant, which makes it difficult to draw universal conclusions based on a single taxonomic group. Unicellular and multicellular organisms were compared for their species richness patterns by Hillebrand et al. (2001), whose results indicated that the dispersal ability of some taxonomic groups (benthic diatoms or ciliates) is rather restricted, and ubiquity is probably not as high as was thought.

Studies comparing the factors driving community composition among different taxonomic groups of micro-organisms are rarer than those comparing species richness and spatial distribution. The importance of $\mathrm{pH}$ and moisture has been documented for particular groups of micro-organisms (Berzins \& Pejler 1987; Mieczan 2009; Cantonati \& Spitale 2009), but the effects of substratum structure on different micro-organisms has not been compared. In addition, studies have often focused only on one habitat type (bogs for testate amoebae or littoral zones of lakes for rotifers). We therefore chose three different taxonomic groups of micro-organisms: diatoms, testate amoebae and monogonont rotifers, which we studied along a gradient of mineral richness, from extremely mineral-rich spring-fens to mineral-poor Sphagnum-fens. Diatoms are unicellular, silica-forming autotrophic organisms which can fix energy from the sun and thus form the base of the food chain (Round et al. 1990); testate amoebae represent a group of unicel- lular, heterotrophic protists producing different types of shells or plates, which often contain silica (Warner 1990); monogonont rotifers are small multicellular aquatic animals characterised by the ability to withstand unfavourable periods in diapause, and by female parthenogenesis allowing rapid population growth under favourable environmental conditions (Ricci 2001; Gilbert 2004; Schröder 2005).

The main aim of our study is to compare responses of three taxonomic groups of micro-organisms, differing in trophy and body structure, to environmental variables. We studied the effects of both substratum (i.e., bryophyte species composition, tuft structure and water content) and water chemistry on species composition. We also compared major gradients in species data and the ability of particular variables to explain species composition within the groups. The following hypotheses were tested: (1) water chemistry is more important for diatoms (autotrophs) than for the other two groups (heterotrophs), because dissolved minerals and nutrients directly affect photosynthesis and autotrophic growth; (2) much of the explained variability will be shared between substratum and water chemistry, because the structure of the bryophyte tuft is influenced by water chemistry (e.g., Sphagnum versus pleurocarpous mosses, Gorham \& Janssens 1992, Paullisen et al. 2004), but at the same time the bryophyte modulates other important variables, such as moisture and light penetration; (3) the assemblage composition of shellbuilding organisms (diatoms and testate amoebae) will be more strongly influenced by dissolved silica concentration than that of monogonont rotifers.

\section{MATERIALS AND METHODS}

\subsection{Study area and sites}

The study area was located on the western margin of the Western Carpathians, stretching along the border between the Czech Republic and Slovakia (48 $56^{\prime}$ $\left.49^{\circ} 32^{\prime} \mathrm{N}, 17^{\circ} 44^{\prime}-18^{\circ} 51^{\prime} \mathrm{E}\right)$. This region forms part of the flysch belt, in which sandstone and claystone of variable calcium contents alternate. The chemical composition of groundwater reflects the rock chemistry (Rapant 1996). Groundwater chemistry varies from calcareous waters, which support cold-water travertine (tufa) formation (in the south of the studied area), through waters rich in calcium, sodium and potassium, without tufa-formation, to acidic waters rich in iron, silica and sulphates but poor in all other elements (in the northernmost part of the studied area) (Hájek et al. 2002). The following four structural habitat types were distinguished along the mineral-richness gradient: (1) calcareous fens with tufa (calcium carbonate) formation, (2) extremely mineralrich fens without tufa formation, (3) mineral-rich and moderately mineral-rich Sphagnum-fens, and (4) mineral-poor acid Sphagnum-fens. On the basis of previous studies (Poulíčková et al. 2005), we chose 13 sites that 
best corresponded to the above-mentioned fen habitat types. Four sites were selected within petrifying springs, three sites within mineral-rich fens without tufa formation, two sites within mineral-rich Sphagnum-fens and four within mineral-poor Sphagnum-fens.

\subsection{Sampling methods and sample processing}

Epiphytic diatoms, testate amoebae and monogonont rotifers were sampled with their substrata (bryophytes). A total of 26 samples of bryophytes were collected in May 2006. At each site, two samples of different bryophyte tufts were collected, representing clearly distinguishable mesohabitats, differing mostly in the composition of the bryophyte tuft and/or water level. Sampled bryophytes were situated in areas with good groundwater supplies and hydrochemistry was constant within the locality. Each bryophyte tuft comprised one dominant species plus a mixture of other bryophyte species. For each sample we determined the percentage abundance of individual bryophyte species, recording a total of 14 moss and one liverwort (Pellia) species. Bryophyte tufts were cut with scissors and transported in a live state in plastic bags to the laboratory. In the laboratory, each bryophyte sample was weighed, washed with $20 \mathrm{~mL}$ of distilled water and thoroughly squeezed to extract micro-organisms. The effectiveness of the washing procedure was $80 \%$ (Hindák 1978). Squeezed bryophytes were dried at $75{ }^{\circ} \mathrm{C}$ for 48 hours and then re-weighed and water content estimated as the difference between fresh and dry bryophyte matter. The extract was fixed with formaldehyde and split into two subsamples, 0.5 $\mathrm{mL}$ of extract being analysed from each. The first subsample was used for processing testate amoebae and rotifers, the second for diatoms. Diatom frustules were mounted in Pleurax. For quantitative evaluation, 400 diatom valves were identified on each permanent slide. Nomenclature followed Kučera \& Váňa (2003) for bryophytes, Krammer \& Lange-Bertalot (1986, 1988, 1991a, b) for diatoms, Aescht \& Foissner (1989) for testate amoebae and Segers (1995) for monogonont rotifers.

Bryophytes were divided into four functional groups: 1) Sphagnum species: $S$. fallax, $S$. flexuosum, $S$. palustre and S. papillosum; 2) crawling (pleurocarpous) species with loose tufts: Brachythecium rivulare, Calliergonella cuspidata and Plagiomnium affine agg. ( $P$. ellipticum, $P$. elatum); 3) crawling (pleurocarpous) species with dense tufts: Cratoneuron filicinum, Palustriella commutata and $P$. decipiens and 4) erect (mostly acrocarpous) species: Bryum pseudotriquetrum, Fissidens adianthoides and Philonotis caespitosa. For each sample, the percentage cover of each bryophyte functional group was determined.

Conductivity (corrected for $\mathrm{H}^{+}$ions and standardised to $20^{\circ} \mathrm{C}$ ) and $\mathrm{pH}$ of the water were measured in situ using portable instruments (WTW Multi 340i/SET). To characterize each site, samples were taken in October 2006. Water samples were collected in autumn due to relative stability of water chemistry (Hájek \& Hekera 2002) and $\mathrm{PO}_{4}^{3-}, \mathrm{NO}_{3}^{-}, \mathrm{Ca}^{2+}, \mathrm{Mg}^{2+}, \mathrm{Si}$ and $\mathrm{Fe}$ content were measured in an accredited laboratory (for details see Hájek \& Hekera 2004).

\subsection{Data analyses}

Principal Component Analysis (PCA) was used to show relationships among explanatory variables. The species abundance data were log-transformed, as $\mathrm{Y}=$ $\log (\mathrm{n}+1)$, to reduce the influence of dominants. Downweighting of rare species was applied in all multivariate analyses. Detrended Correspondence Analysis (DCA) was used to study relationships between species composition and measured variables. Spearman's rank correlations $\left(r_{s}\right)$ were used to examine possible relationships between explanatory variables and site scores on the first two ordination axes. Bonferroni corrections of the significance levels were used for multiple comparisons of environmental variables (Holm 1979). Predictive power of the bryophyte assemblage composition was analysed using site scores on the first three DCA ordination axes. The variation partitioning approach was used to determine the relative variation in testate amoebae, diatom and monogonont rotifer data, explained by two groups of variables (water chemistry and substratum characteristics) in Canonical Correspondence Analyses (CCA). The CCA method was used because of the long species data gradient $(\mathrm{SD} \geq 4)$. Because the ecological gradient spanned calcareous tufa-forming fens to extremely mineral-poor fens tending to ombrotrophy, we assumed unimodal responses for many species, which justifies using CCA rather than RDA (Lepš \& Šmilauer 2003). A forward selection algorithm with the Monte Carlo permutation test (1999) was used to find significant explanatory variables. For each organismal group, the individual and shared effects of water chemistry and substratum characteristics were studied. For this analysis only variables that contributed significantly to the explanation of species data variation were selected. We used a novel variation partitioning algorithm for CCA proposed by Peres-Neto et al. (2006). This algorithm calculates permutation-based adjusted $R^{2}$ values and, unlike the 'classical' algorithm (Borcard et al. 1992), provides an unbiased estimate of the explained variation. We used 1000 permutations to obtain the adjusted $R^{2}$. Note that the adjustment, as well as the use of the unimodal species response model (Økland 1999), markedly decreases the percentage of explained variation. Therefore, the frequent interpretation that 'unexplained variation' is caused by unmeasured environmental variables and stochasticity in biological processes should be carefully reconsidered (Økland 1999). Rather, the relative differences among organismal groups should be seen as the principal results of our analyses. Permutational multivariate analysis of variance using distance matrices (PERMANOVA; command 'adonis' from the 'vegan' 


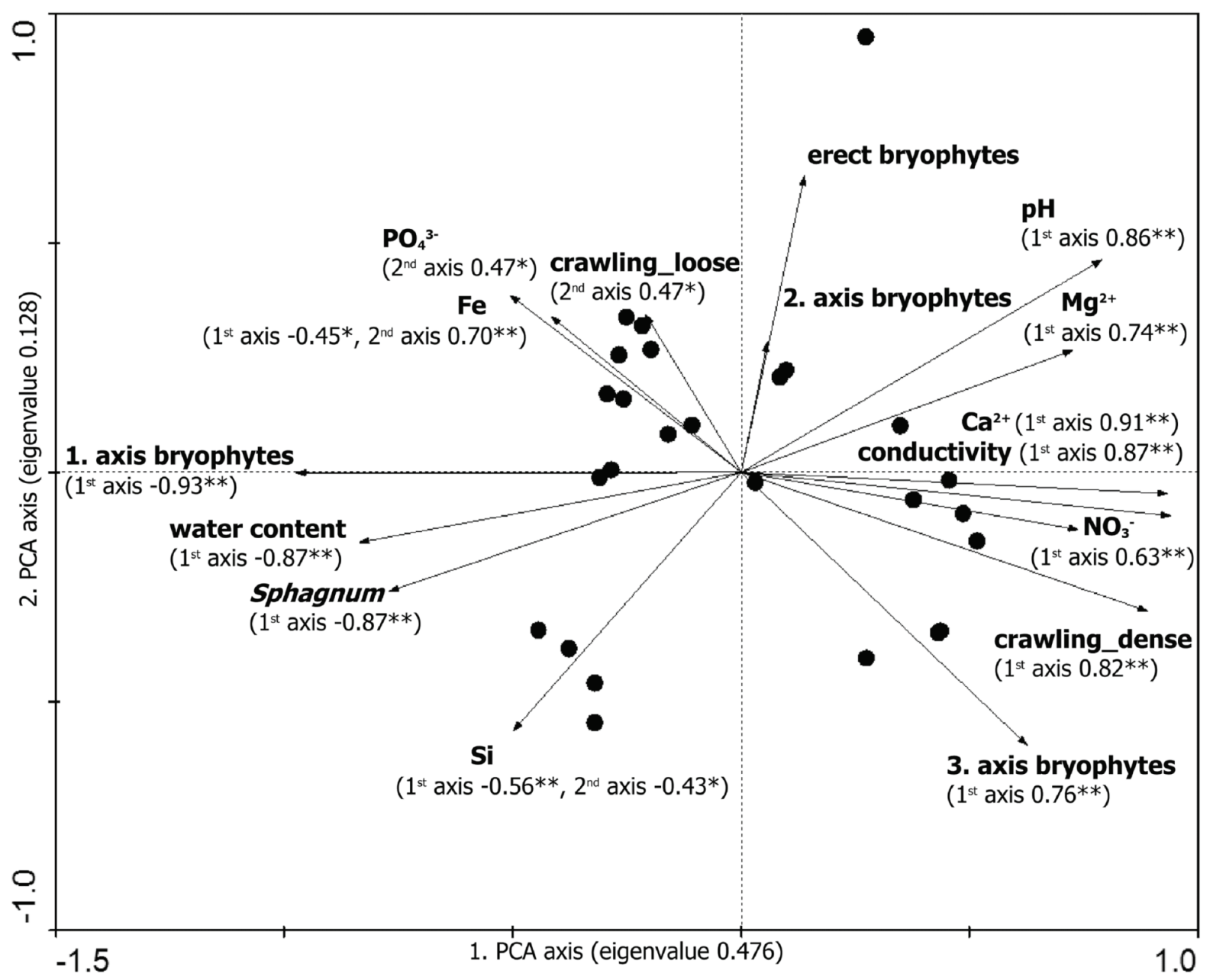

Fig. 1. PCA diagram of sixteen explanatory variables on the first two ordination axes. Eigenvalues of axes, correlations of explanatory variables with the first two PCA axes $\left(r_{s}\right)$ and their significance $(* * p<0.003 ; * p<0.05)$ are given in parentheses. Only significant correlations are shown.

library; Anderson 2001; McArdle \& Anderson 2001) was used to evaluate whether there were statistically significant differences in testate amoebae, diatom and monogonont rotifer assemblages between crawling dense, crawling loose and Sphagnum tufts. Erect tufts were not analysed because there were insufficient number of samples. The CANOCO 4.5 package (ter Braak \& Šmilauer 2002) and R software were used for multi-dimensional analyses and STATISTICA 8 (Hill \& Lewicki 2007) for uni-dimensional analyses.

\section{RESULTS}

\subsection{Relationships among measured variables}

Many of the explanatory variables were inter-correlated, as is illustrated by the PCA ordination diagram of sixteen environmental variables in figure 1 . The first PCA axis was positively correlated with water chemistry variables $\left(\mathrm{pH}\right.$, conductivity, $\mathrm{Ca}^{2+}, \mathrm{Mg}^{2+}, \mathrm{NO}_{3}{ }^{-}$), bryophyte composition of the sample (the third DCA axis) and abundance of dense crawling bryophytes. Other substratum (the first DCA bryophyte axis, water content, Sphagnum dominance) and water chemistry characteristics $\left(\mathrm{PO}_{4}^{3-}, \mathrm{Si}\right)$ were negatively correlated with the first PCA axis. The second PCA axis was particularly correlated with the acidic part of the gradient (Fig. 1), positively with $\mathrm{PO}_{4}{ }^{3-}, \mathrm{Fe}$ and abundance of loose crawling bryophytes, and negatively with $\mathrm{Si}$. Abundance of erect bryophytes and the second DCA axis of bryophytes were correlated with the second PCA axis in the alkaline part of the gradient, but these correlations were not significant. The correlations suggested that the Sphagnum-dominated samples were characterised by rather high water content and Si concentration, whereas samples dominated by loose crawling bryophytes had higher iron and phosphate concentrations.

\subsection{Variation in bryophyte assemblages}

Species composition of bryophytes as a substratum was closely related to the gradient of mineral-richness (Fig. 2). Species were arranged along the first DCA axis from calciphilous species (Bryum pseudotriquetrum, Palustriella commutata), through meadow species 


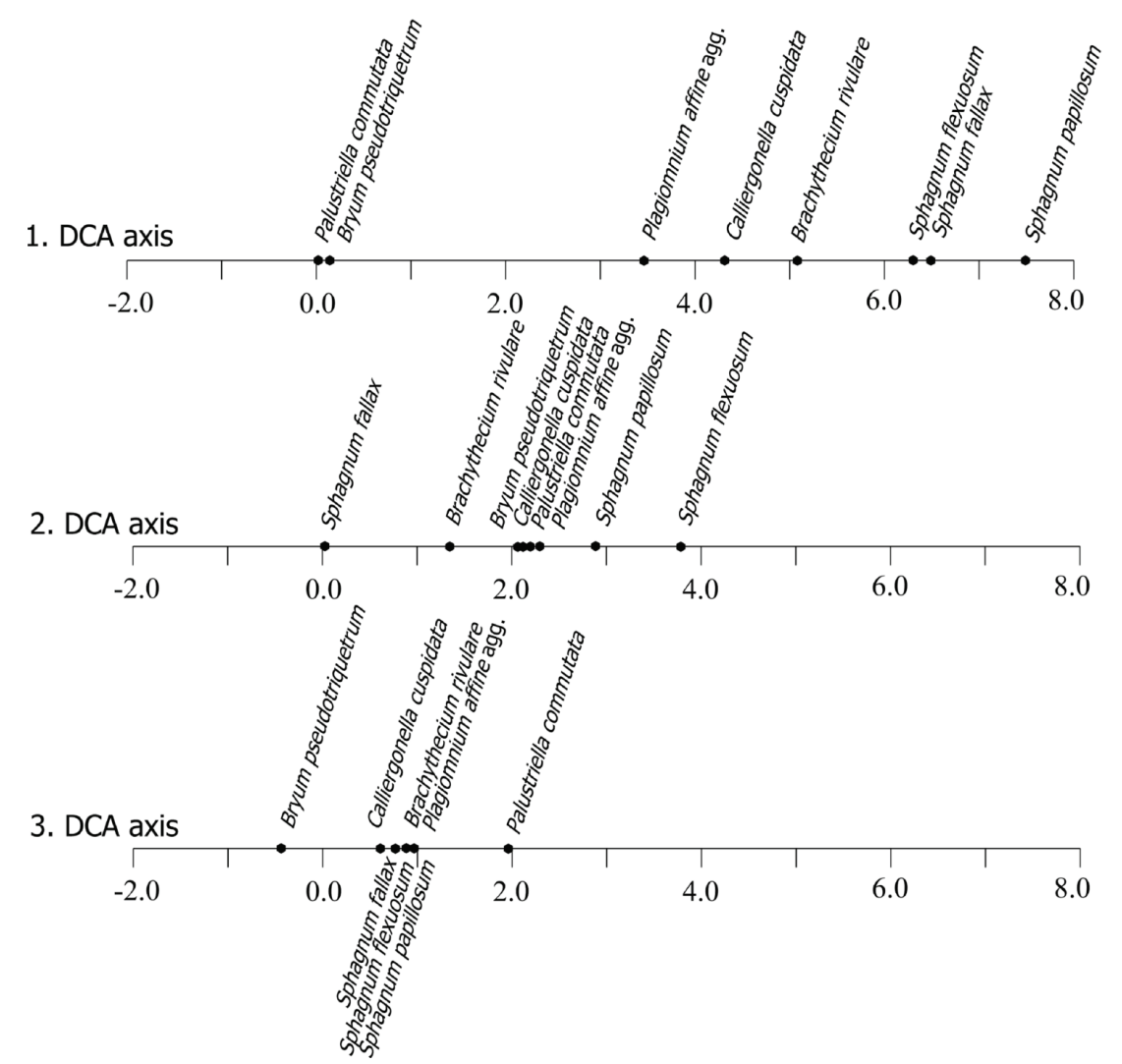

Fig. 2. Position of bryophyte species along the three DCA axes. Only species with a fit $>10 \%$ are shown. The first axis explains $21.0 \%$ of species data, the second axis $17.1 \%$ and the third axis $9.6 \%$.

inhabiting mostly moderately calcium-rich spring fens, to Sphagnum species in acidic, mineral-poor stands (Fig. 2). The second gradient (the second DCA axis) in bryophyte species composition was developed only in the acidic part of the first DCA axis. Species were ordered from S. flexuosum, occupying mineral-poor fen springs, through $S$. papillosum and meadow species (e.g., Brachythecium rivulare) which were co-dominants with other Sphagnum species, to $S$. fallax, which occupied the most acidic, often drier microhabitats. On the other hand, the third DCA axis was only displayed in the calcium-rich part of the first DCA axis. Erect species (mostly Bryum pseudotriquetrum) were positioned at one end of the third axis, and dense crawling species (mostly Palustriella commutata) at the opposite end. PERMANOVA showed that the species composition of all groups (i.e., testate amoebae, diatoms and monogonont rotifers) differed significantly $(P<0.01)$ among crawling dense, crawling loose and Sphagnum tufts.

\subsection{Major gradients and variation in micro-organism species data}

The assemblages of all three groups displayed very sharp compositional gradients, correlated with water $\mathrm{pH}$ and conductivity, calcium concentration and dominance of Sphagnum (Tab. 1). While the second major gradient in species composition of diatoms and testate amoebae was correlated with measured variables (substratum structure and water content), that of rotifers remained unexplained. The second compositional axis of diatoms was explained by more measured variables (also by water-chemistry variables) compared to testate amoebae. When we compared the variation explained by environmental variables in particular CCA analyses, the variables connected with substratum structure explained slightly more variation in species data than the water chemistry variables (see Appendix). The most important water chemistry variables were those related to base saturation (i.e., $\mathrm{pH}$, water conductivity and calcium concentration). They explained the highest percentage of variation in species data for all three groups (Tab. 2). While testate amoeba composition was also influenced by phosphates and silica, and that of diatoms by nitrates, silica and iron, no other water chemistry variable contributed to the explanation of monogonont rotifer data (Tab. 2). Within the substratum variables, abundance of Sphagnum was the variable which explained most variation in diatoms and testate amoebae, whereas bryophyte species composition, expressed by the first DCA axis, explained most variation in monogonont rotifers. For diatoms, water content also contributed to the explanation of species variation (Tab. 2). When both substratum and water chemistry variables were analysed together in a single CCA with forward selection (Tab. 3), substratum variables (the first DCA axis and/or abundance of Sphagnum) were the most important for all three groups. 
Tab. 1. Correlations between explanatory variables (substratum and water chemistry) and sample scores on the first two ordination axes, based on DCA analyses performed separately for diatoms, testate amoebae and rotifers. Values of Spearman's correlation coefficient $\left(r_{s}\right)$ and their significance $(p)$ are shown; significant correlations after Bonferroni correction are in bold $(* * p<0.003)$ and significance of $p=0.05(*)$ are in italics.

\begin{tabular}{|c|c|c|c|c|c|c|c|c|c|c|c|c|}
\hline & \multicolumn{4}{|c|}{ Diatoms } & \multicolumn{4}{|c|}{ Testate amoebae } & \multicolumn{4}{|c|}{ Monogonont Rotifers } \\
\hline & \multicolumn{2}{|c|}{ 1. axis DCA } & \multicolumn{2}{|c|}{ 2. axis DCA } & \multicolumn{2}{|c|}{ 1. axis DCA } & \multicolumn{2}{|c|}{ 2. axis DCA } & \multicolumn{2}{|c|}{ 1. axis DCA } & \multicolumn{2}{|c|}{ 2. axis DCA } \\
\hline & $r_{s}$ & $p$ & $r_{s}$ & $p$ & $r_{s}$ & $p$ & $r_{s}$ & $p$ & $r_{s}$ & $p$ & $r_{s}$ & $p$ \\
\hline water content & 0.60 & $* *$ & 0.49 & $*$ & 0.47 & * & -0.47 & $*$ & 0.81 & $* *$ & -0.10 & n.s. \\
\hline Sphagnum & 0.88 & $* *$ & 0.15 & n.s. & 0.88 & $* *$ & -0.06 & n.s. & 0.78 & $* *$ & -0.17 & n.s \\
\hline erect bryophytes & -0.31 & n.s. & -0.43 & $*$ & -0.36 & n.s. & 0.30 & n.s. & -0.40 & $*$ & 0.13 & n.s. \\
\hline crawling_loose tufts & -0.11 & n.s. & 0.53 & $*$ & 0.02 & n.s. & -0.17 & n.s. & 0.12 & n.s. & 0.36 & n.s. \\
\hline crawling_dense tufts & -0.74 & $* *$ & -0.64 & $* *$ & -0.81 & $* *$ & 0.19 & n.s. & -0.81 & $* *$ & -0.04 & n.s. \\
\hline 1. DCA axis bryophytes & 0.94 & $* *$ & 0.42 & $*$ & 0.96 & $* *$ & -0.17 & n.s. & 0.88 & $* *$ & -0.04 & n.s. \\
\hline 2. DCA axis bryophytes & -0.11 & n.s. & -0.19 & n.s. & -0.09 & n.s. & 0.28 & n.s. & -0.17 & n.s. & -0.24 & n.s. \\
\hline 3. DCA axis bryophytes & -0.63 & $* *$ & -0.20 & n.s. & -0.63 & $* *$ & -0.01 & n.s. & -0.60 & $*$ & -0.10 & n.s. \\
\hline $\mathrm{pH}$ & -0.82 & $* *$ & -0.43 & $*$ & -0.76 & $* *$ & 0.37 & n.s. & -0.79 & $* *$ & -0.01 & n.s. \\
\hline conductivity & -0.86 & $* *$ & -0.38 & n.s. & -0.88 & $* *$ & 0.14 & n.s. & -0.84 & $* *$ & 0.09 & n.s. \\
\hline $\mathrm{Ca}^{2+}$ & -0.87 & $* *$ & -0.40 & $*$ & -0.89 & $* *$ & 0.20 & n.s. & -0.88 & $* *$ & 0.12 & n.s. \\
\hline $\mathrm{Mg}^{2+}$ & -0.80 & $* *$ & -0.15 & n.s. & -0.69 & $* *$ & -0.02 & n.s. & -0.59 & $* *$ & 0.15 & n.s. \\
\hline $\mathrm{Si}$ & 0.56 & $* *$ & 0.33 & n.s. & 0.56 & $*$ & -0.36 & n.s. & 0.56 & $*$ & -0.05 & n.s. \\
\hline $\mathrm{Fe}$ & 0.47 & $*$ & 0.51 & $*$ & 0.45 & $*$ & 0.24 & n.s. & 0.41 & $*$ & -0.03 & n.s. \\
\hline $\mathrm{NO}_{3}^{-}$ & -0.70 & $* *$ & -0.30 & n.s. & -0.62 & $* *$ & -0.12 & n.s. & -0.52 & $*$ & -0.15 & n.s. \\
\hline $\mathrm{PO}_{4}{ }^{3-}$ & 0.34 & n.s. & 0.21 & n.s. & 0.29 & n.s. & 0.54 & $*$ & 0.11 & n.s. & 0.09 & n.s. \\
\hline
\end{tabular}

Tab. 2. Results of forward selection in six separate CCAs, which identified variables that contributed significantly to the explanation of species data variation for the two groups of variables (substrate and water chemistry), separately for diatoms, testate amoebae and monogonont rotifers. Statistically significant variables were used in partioning the effects of water chemistry and substratum in the subsequent analysis (Fig. 3). Explanatory variables are ordered according to the order in forward selection. Significant variables are in bold $(* * * p<0.001, * * p<0.01, * p<0.05)$.

\begin{tabular}{|c|c|c|c|c|c|}
\hline \multirow[b]{2}{*}{ Substratum } & \multicolumn{5}{|c|}{ Diatoms } \\
\hline & $\%$ & Lambda & Water chemistry & $\%$ & Lambda \\
\hline Sphagnum & $19.7 * * *$ & 0.554 & $\mathrm{pH}$ & $17.8 * * *$ & 0.500 \\
\hline 1. DCA axis bryophytes & $9.4 * * *$ & 0.264 & conductivity & $7.8 * * *$ & 0.218 \\
\hline water content & $5.2 * *$ & 0.147 & $\mathrm{NO}_{3}^{-}$ & $6.2 * *$ & 0.173 \\
\hline 3. DCA axis bryophytes & 4.1 & 0.116 & $\mathrm{Ca}^{2+}$ & $6.3 * *$ & 0.178 \\
\hline erect bryophytes & 4.1 & 0.115 & $\mathrm{Si}$ & $5.1^{*}$ & 0.144 \\
\hline crawling loose tufts & 3.8 & 0.106 & $\mathrm{Mg}^{2+}$ & $5.1^{*}$ & 0.142 \\
\hline crawling_dense tufts & 3.7 & 0.104 & $\mathrm{Fe}$ & $4.3^{*}$ & 0.120 \\
\hline \multirow[t]{2}{*}{ 2. DCA axis bryophytes } & 3.5 & 0.098 & $\mathrm{PO}_{4}{ }^{3-}$ & 3.9 & 0.109 \\
\hline & \multicolumn{5}{|c|}{ Testate amoebae } \\
\hline Substratum & $\%$ & Lambda & Water chemistry & $\%$ & Lambda \\
\hline Sphagnum & $21.3 * * *$ & 0.377 & conductivity & $18.1 * * *$ & 0.321 \\
\hline 1. DCA axis bryophytes & $7.5 * * *$ & 0.132 & $\mathrm{PO}_{4}^{3-}$ & $6.7 * *$ & 0.119 \\
\hline 3. DCA axis bryophytes & $5.6 *$ & 0.099 & $\mathrm{Si}$ & $5.8 * *$ & 0.102 \\
\hline erect bryophytes & 5.5 & 0.098 & $\mathrm{pH}$ & 4.0 & 0.069 \\
\hline water content & 5.4 & 0.096 & $\mathrm{Fe}$ & 3.9 & 0.069 \\
\hline 2. DCA axis bryophytes & 5.1 & 0.091 & $\mathrm{NO}_{3}^{-}$ & 3.0 & 0.053 \\
\hline crawling_dense tufts & 4.5 & 0.079 & $\mathrm{Ca}^{2+}$ & 2.8 & 0.050 \\
\hline \multirow[t]{2}{*}{ crawling_loose tufts } & 2.9 & 0.052 & $\mathrm{Mg}^{2+}$ & 2.7 & 0.048 \\
\hline & \multicolumn{5}{|c|}{ Monogonont Rotifers } \\
\hline Substratum & $\%$ & Lambda & Water chemistry & $\%$ & Lambda \\
\hline 1. DCA axis bryophytes & $17.8 * * *$ & 0.235 & $\mathrm{Ca}^{2+}$ & $15.0 * * *$ & 0.204 \\
\hline Sphagnum & $11.1 * * *$ & 0.151 & $\mathrm{pH}$ & $6.0 *$ & 0.082 \\
\hline water content & 3.8 & 0.052 & $\mathrm{Fe}$ & 3.8 & 0.052 \\
\hline crawling_dense tufts & 3.2 & 0.043 & conductivity & 3.6 & 0.049 \\
\hline crawling_loose tufts & 2.9 & 0.039 & $\mathrm{Mg}^{2+}$ & 3.6 & 0.049 \\
\hline 2. DCA axis bryophytes & 2.4 & 0.033 & $\mathrm{NO}_{3}^{-}$ & 3.2 & 0.043 \\
\hline erect bryophytes & 1.8 & 0.025 & $\mathrm{PO}_{4}{ }^{3-}$ & 2.9 & 0.039 \\
\hline 3. DCA axis bryophytes & 1.0 & 0.013 & $\mathrm{Si}$ & 2.8 & 0.038 \\
\hline
\end{tabular}


Tab. 3. The results of stepwise selection of the explanatory variables using forward selection in a total CCA of all variables for individual taxonomic groups. Lambda value, percentage of explained variation, and order in forward selection are given for each variable. Significant variables are in bold $\left(* * * \mathrm{p}<0.001, * * p<0.01, *^{*}<0.05\right)$.

\begin{tabular}{|c|c|c|c|c|c|c|c|c|c|}
\hline & \multicolumn{3}{|c|}{ Diatoms } & \multicolumn{3}{|c|}{ Testate amoebae } & \multicolumn{3}{|c|}{ Monogonont Rotifers } \\
\hline & Order & Lambda & $\%$ & Order & Lambda & $\%$ & Order & Lambda & $\%$ \\
\hline 1. DCA axis bryophytes & 2. & 0.264 & $9.4 * * *$ & 13. & 0.039 & 2.2 & 1. & 0.235 & $17.2 * * *$ \\
\hline 2. DCA axis bryophytes & 13. & 0.076 & 2.7 & 7. & 0.061 & 3.4 & 12. & 0.037 & 2.7 \\
\hline 3. DCA axis bryophytes & 7. & 0.116 & $4.1^{*}$ & 9. & 0.053 & 3.0 & 8. & 0.057 & 4.2 \\
\hline water content & 10. & 0.094 & 3.3 & 6. & 0.080 & 4.5 & 11. & 0.043 & 3.2 \\
\hline Sphagnum & 1. & 0.554 & $19.7 * * *$ & 1. & 0.377 & $21.3^{* * *}$ & 2. & 0.149 & $10.9 * * *$ \\
\hline erect bryophytes & 14. & 0.070 & 2.5 & 4. & 0.106 & 6.0* & 15. & 0.026 & 1.9 \\
\hline crawling_loose tufts & 15. & 0.054 & 1.9 & 14. & 0.028 & 1.6 & 16. & 0.024 & 1.8 \\
\hline crawling_dense tufts & 16. & 0.053 & 1.9 & 15. & 0.028 & 1.6 & 3. & 0.060 & 4.4 \\
\hline $\mathrm{pH}$ & 3. & 0.164 & $5.8^{* *}$ & 10. & 0.046 & 2.6 & 6. & 0.048 & 3.5 \\
\hline conductivity & 11. & 0.085 & 3.0 & 2. & 0.132 & $7.5^{* * *}$ & 7. & 0.048 & 3.5 \\
\hline $\mathrm{Ca}^{2+}$ & 12. & 0.08 & 2.8 & 11. & 0.044 & 2.5 & 4. & 0.050 & 3.7 \\
\hline $\mathrm{Mg}^{2+}$ & 4. & 0.151 & $5.4^{* * *}$ & 16. & 0.028 & 1.6 & 5. & 0.048 & 3.5 \\
\hline $\mathrm{PO}_{4}{ }^{3-}$ & 8. & 0.106 & 3.8* & 3. & 0.111 & $6.3^{* *}$ & 13. & 0.035 & 2.6 \\
\hline $\mathrm{NO}_{3}^{-}$ & 6. & 0.133 & $4.7^{* *}$ & 12. & 0.044 & 2.5 & 14. & 0.021 & 1.5 \\
\hline $\mathrm{Si}$ & 5. & 0.147 & $5.2^{* *}$ & 5. & 0.090 & $5.1 * *$ & 9. & 0.046 & 3.4 \\
\hline $\mathrm{Fe}$ & 9. & 0.098 & 3.5 & 8. & 0.055 & 3.1 & 10. & 0.044 & 3.2 \\
\hline
\end{tabular}

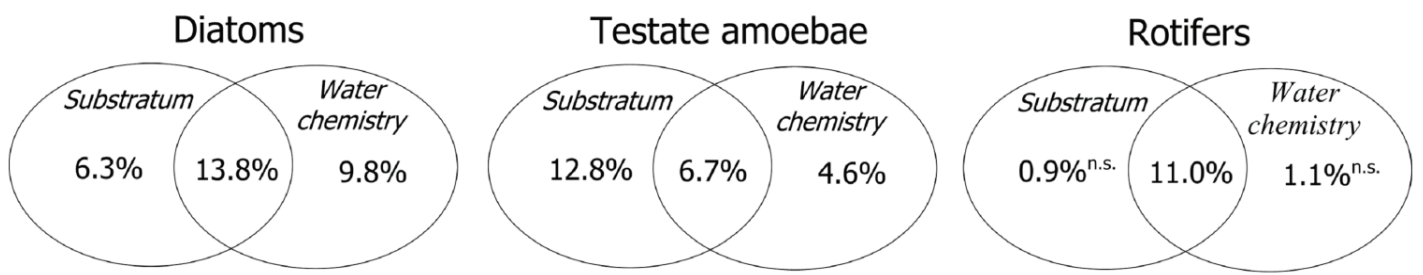

Fig. 3. Results of variation partitioning for particular taxonomic groups. Individual and shared effects of water chemistry and substratum are expressed as adjusted percentages of the total variation in species data. The significance of particular effects was tested using the Monte Carlo permutation test with 1000 runs. Non-significant effects are indicated by the abbreviation 'n.s.'. Only significant variables from both variable groups were used for the analysis (see Tab. 2).

Besides structural variables, some water-chemistry variables contributed significantly to explain diatom $(\mathrm{pH}$, magnesium, phosphates, nitrates, silica) and testate amoeba (water conductivity, phosphates, silica) species composition, while structural variables alone sufficiently explained species-data variation in monogonont rotifers.

\subsection{Individual effects of two different variable groups}

When variations caused by substratum characteristics and water chemistry were partitioned out, the individual effect of these two variables differed for particular taxonomic groups, ranging between $0.9 \%$ and $12.8 \%$ in adjusted values (Fig. 3). Testate amoebae were controlled by substratum rather than by water chemistry (water chemistry:substratum ratio was 0.4 ), in contrast to diatoms for which water chemistry effects prevailed over substratum effects (water chemistry:substratum ratio 1.56). Monogonont rotifers showed virtually no individual effect of either substratum characteristics or water chemistry. Individual effects reached only $1 \%$ of explained variation and were not significant. Shared effects of both variable groups predominated over total individual effects in the rotifer data (individual:shared effect ratio was 0.18 ), whereas individual effects were dominant in diatom and testate amoeba data (individual:shared effect ratios were 1.16 and 2.6, respectively).

\section{DISCUSSION}

\subsection{Differences among taxonomic groups in response to chemical and substratum variables}

Assemblages of all three taxonomic groups displayed very sharp compositional gradients across the study area correlated with water $\mathrm{pH}$, conductivity and calcium concentration, like vascular plants and bryophytes (Hájek et al. 2002), as well as molluscs (Horsák \& Hájek 2003; Horsák \& Cernohorsky 2008). In addition, these major gradients were linked to some substratum characteristics. Therefore, the deterministic role of $\mathrm{pH}$ and calcium on species composition can be considered a general rule that is valid for micro- and macroorganisms, supporting the validity of some, more general, ecological concepts, such as the evolutionary species pool with respect to $\mathrm{pH}$ (Pärtel 2002; Hájek et al. 2007).

We also discovered several differences in micro-organismal behaviour. We found that phosphates contributed significantly to explaining variation in testate amoeba assemblages. An apparent response of testacean species composition and biomass to phosphorus concentration was shown using experimental fertilization in Alaskan fens (Mitchell 2004). This might be mediated by changing the availability of prey species for testate 
amoebae. A similar study by Mieczan (2009) in Poland revealed a significant effect of total phosphorus on the occurrence of testate amoebae and, like Mitchell (2004), he hypothesised indirect effects of phosphorus on testacean food abundance.

Diatoms differ from the other two taxonomic groups in their response to nitrates, which partially explained their species composition. Different authors found that nitrate concentration affected the development and composition of diatom assemblages (Aboal et al. 1998; Bertrand et al. 1999; Cantonati et al. 2007; Soininen 2007; Cantonati \& Spitale 2009) and that nitrates increased the relative importance of diatoms at the expense of other groups of micro-organisms, such as testae amoebae (Gilbert et al. 1998b). Nitrogen occurs as nitrate mainly in mineral-rich fens, whereas the $\mathrm{NH}_{4}{ }^{+}$ form prevails in mineral-poor fens (Hájek et al. 2002). This was reflected in positive correlations between water mineral-richness $(\mathrm{pH}$, conductivity) and nitrates (data not shown). In our study area, mineral-rich fens were inhabited by eutraphentic species (e.g., Navicula elginensis, $N$. veneta and Surirella angusta) that were not present in mineral-poor fens. Cantonati et al. (2001) found that most taxa included in the higher trophic categories were also alkaliphilous. Eutraphentic diatoms are often found in springs and streams affected by organic pollution, often of anthropogenic origins (Bertrand et al. 1999; Cantonati \& Spitale 2009). One of the tufa-forming fens was influenced by cattle grazing, which caused an increase in nitrate concentrations. This was reflected in the occurrence of eutraphentic taxa, Navicula trivialis and Cocconeis placentula.

In agreement with our hypothesis, silica was one of the statistically significant variables explaining variation in the shell-building organisms (diatoms and testate amoebae), whereas it did not contribute to explaining any variation in the monogonont rotifer assemblages (Tabs 2 and 3). Silica is a major limiting nutrient for diatom growth and hence is a controlling factor in primary productivity (Martin-Jézéquel et al. 2000). Although Cantonati et al. (2006) reported that silica concentrations in springs almost never reached limiting values $\left(<0.1 \mathrm{mg} \mathrm{L}^{-1}\right)$, our study showed a significant influence of silica concentrations on diatom species composition, even if silica concentration was rather high (minimum value $5.5 \mathrm{mg} \mathrm{L}^{-1}$ ). The possible effect of silica availability on diatoms, even in such a silica-rich environment, is supported by our observations of poorly silicified diatom frustules, but this phenomenon requires further study.

\subsection{Relative importance of water chemistry and substratum}

For diatoms, we found the highest proportion of variation was explained by water chemistry rather than substratum characteristics. This agrees with our initial hypothesis that autotrophic organisms will be more influenced by dissolved mineral concentrations than heterotrophic organisms. Water chemistry, especially $\mathrm{pH}$ and conductivity, is considered to be the most important environmental factor influencing diatom assemblages (Cantonati 1998; Poulíčková et al. 2004; Cantonati et al. 2001, 2006; Fránková et al. 2009). The variation of rotifer assemblages was almost completely explained by substratum characteristics and water chemistry, with no significant individual effect, contrary to diatoms and testate amoebae. This means that the monogonont rotifer species composition is not influenced by any chemical factors, other than $\mathrm{pH}$ and calcium, which are the same factors that influence their substratum (Sphagnum occurrence, composition of bryophyte tufts). This agreed with our prediction on possible differences between uni- and multicellular organisms, but more research into other multicellular organisms is needed before general conclusions can be drawn.

The contrasting behaviour of monogonont rotifers could be caused by several factors. Rotifers do not need silica for shells, unlike the other two groups. Furthermore, rotifer species composition did not significantly respond (directly) to inorganic nutrients (phosphates, nitrates). Similar results have been reported from lakes, where rotifers responded to shifts in trophic state (from oligotrophic to mesotrophic or eutrophic) by markedly increased abundance rather than changing species composition (Ejsmont-Karabin \& Hillbricht-Ilkowsks 1994; May \& O'Hare 2005). However, experimental nutrient enrichment in peatlands did not change rotifer biomass (Gilbert et al. 1998b). Rotifers are able to survive unfavourable conditions in diapause (Gilbert 2004; Schröder 2005; etc.), which could enable them to withstand perturbations such as water level decreases. In previous reports (Bartoš 1946; Koniar 1955), the occurrence of both bdelloid and monogonont rotifers on bryophytes was considered to be dependent on moisture and the ability to survive drying out, while testate amoebae were considered even more sensitive to moisture (Bartoš 1946; De Graaf 1956). More recently, it was shown that bryophyte-dwelling testate amoebae and diatoms were dependent on moisture (e.g., Mitchell et al. 1999; Van de Vijver et al. 2003; Poulíčková et al. 2004), whereas no other ecological studies focusing on rotifers dwelling in bryophytes have been performed. In our study, the water content of bryophyte tufts explained a relatively high proportion of variation in species data of all three groups, but the water content effect was not independent of other environmental variables (see Tab. 3).

\subsection{Host specificity}

Even though our research was not designed to test host specificity directly, our results suggest some relationships between species composition of microbial assemblages and taxonomic identity of dominant bryophytes. Correlations between microbial species compo- 
sition and substratum characteristics were found for all studied groups (Tab. 1). Dominance of Sphagnum and the first DCA axis of bryophyte composition also explained more variation than water chemistry variables, which is in accordance with the ability of Sphagnum to retain high amounts of water in dry periods, to acidify mire water, and thus create a unique microhabitat for microscopic organisms (Hingley 1993). The effect of substratum characteristics was however largely shared with the effect of water chemistry, suggesting that both water chemistry and substratum influenced microbial communities. Bryophytes respond to changes in environmental conditions in a very complex way and this could explain why bryophyte species composition explained a higher proportion of variation in microbial assemblages than particular environmental variables (see also Opravilová \& Hájek 2006). Bryophytes also modulate other, not easily measured environmental variables, such as light, which could be a very important factor influencing microbial species composition. Mieczan (2009) reported the different vertical distribution of testate amoebae in various bryophyte species. It seems that different bryophytes can create very specific microenvironments. This could be the reason why some studies have reported correlations between microbial and bryophyte species composition, independent of other measured variables (e.g., Pouličková et al. 2004, Lamentowicz et al. 2010). In our study, the individual effect of substratum composition (Sphagnum dominance, the first and third DCA axis) sharply exceeded the effect of water chemistry for explaining testate amoeba composition.

\section{CONCLUSIONS}

Fen assemblages of all three taxonomic groups displayed very sharp compositional gradients, correlated with mineral richness and base saturation, which supports some general ecological concepts postulated based on macro-organisms. In addition to water chemistry, species composition of bryophyte substratum had high predictive value for species composition of assemblages of all taxonomic groups. Particular groups of micro-organisms, however, differed in their response to other water chemistry variables and whether the effects of water chemistry and substratum characteristics on species composition are shared. Species composition of silica-forming organisms (diatoms, testate amoebae) responded to silica concentration, that of testate amoebae to phosphates and that of diatoms to nitrates. Autotrophic organisms were more influenced by water chemistry (independent of substratum structure and composition) than heterotrophic ones. Because our conclusions are based on a rather small data set with respect to the number of unique fens, their general validity needs to be verified by other studies in different regions, and by more extensive studies over larger areas and more groups of micro-organisms.

\section{ACKNOWLEDGMENTS}

This research was supported by the long-term research plans of the Masaryk University (MSM 0021622416) and Institute of Botany, Academy of Sciences (AVZ0Z60050516), and the research projects of the Czech Science Foundation (526/09/H025 and P505/11/0779).

\section{REFERENCES}

Aboal, M., M.A. Puig \& M. Prefasi. 1998. Diatom assemblages in springs in Castellón province, Eastern Spain. Arch. Hydrobiol., Suppl. Alg. Stud., 90: 79-95.

Anderson, M.J. 2001. A new method for non-parametric multivariate analysis of variance. Austral Ecol., 26: 32-46.

Bartoš, E. 1946. Rozbor drobnohledné zvířeny českých mechů (The analysis of the microscopical fauna of the Bohemian mosses). Věstník Čsl. zoologické společnosti, 10: 55-80.

Bertrand, J., J.P. Renon \& O. Monnier. 1999. Les diatomées des sources du rebord karstique de la Beauce de la région orléanaise. Symbioses, 1: 3-14.

Bertrand, J., J.P. Renon, O. Monnier \& L. Ector. 2004. Relation «diatomées épiphytes-bryophytes» dans les tourbiéres du Mont Lozère (France) (Relationship "epiphytic diatoms-Bryophytes" at Mount Lozère peat bogs (France)). Vie Milieu, 54: 59-70.

Berzins, B. \& B. Pejler. 1987. Rotifer occurrence in relation to pH. Hydrobiologia, 147: 107-116.

Bohonak, A.J. \& D.G. Jenkins. 2003. Ecological and evolutionary significance of dispersal by freshwater invertebrates. Ecol. Lett., 6: 783-796.

Borcard, D., P. Legendre \& P. Drapeau. 1992. Partialling out the spatial component of ecological variation. Ecology, 73: 1045-1055.

Cáceres, C.E. 1997. Dormancy in invertebrates. Invertebr. Biol., 116: 371-383.

Cantonati, M. 1998. Diatom communities of springs in the southern Alps. Diatom Res., 13: 201-220.

Cantonati, M., G. Corradini, I. Jüttner \& E.J. Cox. 2001. Diatom assemblages in high mountain streams of the Alps and the Himalaya. Nova Hedwigia, 123: 37-61.

Cantonati, M., R. Gerecke \& E. Bertuzzi. 2006. Springs of the Alps, sesitive ecosystems to environmental change: From biodiversity assessment to long-term studies. Hydrobiologia, 562: 59-96.

Cantonati, M., E. Rott, P. Pfister \& E. Bertuzzi. 2007. Benthic algae in springs: Biodiversity and sampling methods. In: M. Cantonati, E. Bertuzzi \& D. Spitale (Eds), The spring habitat: biota and sampling methods. Museo Tridentino di Scienze Naturali, Trento: 77-112

Cantonati, M. \& D. Spitale. 2009. The role of environmental variables in structuring epiphytic and epilithic diatom assemblages in springs and streams of the Dolomity Bellunesi National Park (south-eastern Alps). Fund. Appl. Limnol., 174: 117-133.

Corbet, S.A. 1973. An illustrated introduction to the testate rhizopods in Sphagnum, with special reference to the area around Malham Tarn, Yorkshire. Field Studies, 3: 801-838.

Cox, E.J. 1988. Has the role of the substratum been underestimated for algal distribution patterns in freshwater ecosystems? Biofouling, 1: 49-63.

De Graaf, F. 1956. Studies on Rotatoria and Rhizopoda from the Netherlands. Dodonaea, 23: 145-216.

Ejsmont-Karabin, J. \& A. Hillbricht-Ilkowska. 1994. Illustration of the eutrophication process: comparison of rotifers from Mikolajskie Lake in the years 1989-1990 and 19631964. Pol. Arch. Hydrobiol., 41: 477-487.

Fontaneto, D., T.G. Barraclough, K. Chen, C. Ricci \& E.A. Herniou. 2008. Molecular evidence for broad-scale distri- 
bution in bdelloid rotifers: everything is not everywhere but most things are very widespread. Mol. Ecol., 17: 31363146.

Fránková, M., J. Bojková, A. Poulíčková \& M. Hájek. 2009. The structure and species richness of the diatom assemblages of the Western Carpathian spring fens along the gradient of mineral richness. Fottea, 9: 355-368.

Gilbert, J.J. 2004. Population density, sexual reproduction and diapause in monogonont rotifers: new data for Brachiorus and a review. J. Limnol., 63 (Suppl. 1): 32-36.

Gilbert, D., C. Amblard, G. Bourdier \& A.-J. Francez. 1998a. The microbial loop at the surface of a peatland: structure, function, and impact of nutrient input. Microb. Ecol., 35: 83-93.

Gilbert, D., C. Amblard, G. Bourdier \& A.-J. Francez. 1998b. Short term effect of nitrogen enrichment on the microbial communities of a peatland. Hydrobiologia, 373/374: 111-119.

Gorham, E. \& J.A. Janssens. 1992. Concepts of fen and bog re-examined in relation to bryophyte cover andthe acidity of surface waters. Acta Soc. Bot. Poloniae, 61: 7-20.

Hájek, M. \& P. Hekera. 2004. Can seasonal variation in fen water chemistry influence the reliability of vegetation-environmental analyses? Preslia, 76: 1-14.

Hájek, M., P. Hekera \& P. Hájková. 2002. Spring fen vegetation and water chemistry in the western Carpathian flysch zone. Folia Geobot., 37: 205-224.

Hájek, M., L. Tichý, B. S. Schamp, D. Zelený, J. Roleček, P. Hájková, I. Apostolova \& D. Dítě. 2007. Testing the species pool hypothesis for mire vegetation: exploring the influence of $\mathrm{pH}$ specialists and habitat history. Oikos, 116: 1311-1322.

Hillebrand, H., F. Watermann, R. Karez \& U.G. Berninger. 2001. Differences in species richness patterns between unicellular and multicellular organisms. Oecologia, 126: 114-124.

Hill, T. \& P. Lewicki. 2007. Statistics: methods and applications. StatSoft, Tulsa (http://www.statsoft.com/textbook/ stathome.html).

Hindák, F. 1978. Sladkovodné riasy. SPN, Bratislava: 728 pp.

Hingley, M. 1993. Microscopic life in Sphagnum. Naturalist Handbooks 20. The Richmond publishing Co. Ltd., Slough: $64 \mathrm{pp}$.

Holm, S. 1979. A Simple Sequentially Rejective Multiple Test Procedure. Scand. J. Stat., 6: 65-70.

Horsák, M. 2006. Mollusc community patterns and species response curves along a mineral richness gradient: a case study in fens. J. Biogeogr., 33: 98-107.

Horsák, M. \& M. Hájek. 2003. Composition and species richness of mollusc communities in relation to vegetation and water chemistry in the Western Carpathian spring fens: the poor-rich gradient. J. Mollus. Stud., 69: 349-357.

Horsák, M. \& N. Cernohorsky. 2008. Mollusc diversity patterns in Central European fens: hotspots and conservation priorities. J. Biogeogr., 35: 1215-1225.

Koniar, P. 1955. Príspevok k poznaniu vírnikov (Rotatoria) machov Vysokých Tatier. Biológia, 4: 449-463.

Korhonen, J.J., J. Soininen \& H. Hillebrand. 2010. A quantitative analysis of temporal turnover in aquatic species assemblages across ecosystems. Ecology, 91: 508-517.

Krammer, K. \& H. Lange-Bertalot. 1986. Bacillariophyceae. 1. Teil: Naviculaceae. Süsswasserflora von Mitteleuropa 2/1. Fischer Verlag, Stuttgart: 876 pp.

Krammer, K. \& H. Lange-Bertalot. 1988. Bacillariophyceae. 2. Teil: Bacillariaceae, Epithemiaceae, Surirellaceae. Süsswasserflora von Mitteleuropa 2/2. G. Fischer Verlag, Stuttgart: 896 pp.

Krammer, K. \& H. Lange-Bertalot. 1991a. Bacillariophyceae. 3. Teil: Centrales, Fragilariaceae, Eunotiaceae. Süsswasserflora von Mitteleuropa 2/3. G. Fischer Verlag, Stuttgart: $576 \mathrm{pp}$.
Krammer, K. \& H. Lange-Bertalot. 1991b. Bacillariophyceae. 4. Teil: Achnanthaceae, Kritische Ergänzungen zu Navicula (Lineolate) und Gomphonema. Süsswasserflora von Mitteleuropa 2/4. G. Fischer Verlag, Stuttgart: 437 pp.

Lamentowicz, M., Ł. Lamentowicz, W. van der Knaap, M. Gąbka \& E.A.D. Mitchell. 2010. Contrasting Species-Environment Relationships in Communities of Testate Amoebae, Bryophytes and Vascular Plants Along the FenBog Gradient. Microb. Ecol., 59: 499-510.

Lange-Bertalot, H. 2000. Navicula sensu stricto; 10 genera separated from Navicula sensu stricto; Frustulia. Diatoms of Europe 2, Ruggell: 526 pp.

Lepš, J. \& P. Smilauer. 2003. Multivariate analysis of ecological data using $C A N O C O$. Cambridge University Press, Cambridge: 269 pp.

Linhart, J., S. Vlčková \& V. Uvíra. 2002. Bryophytes as a special mesohabitat for meiofauna in a rip-rapped channel. River Res. Appl., 18: 321-330.

Martin-Jézéquel, V., M. Hildebrand \& M. Brzezinski. 2000. Silica metabolism in diatoms: implications for growth. $J$. Phycol., 36: 821-840.

May, L. \& M. O'Hare. 2005. Changes in rotifer species composition and abundance along a trophic gradient in Loch Lomond, Scotland, UK. Hydrobiologia, 546: 397-404.

McArdle, B.H. \& M.J. Anderson. 2001. Fitting multivariate models to community data: A comment on distance-based redundancy analysis. Ecology, 82: 290-297.

Mieczan, T. 2009. Ecology of testate amoebae (Protists) in Sphagnum peatlands of eastern Poland: Vertical microdistribution and species assemblages in relation to environmental parameters. Annls Limnol., 45: 41-49.

Mitchell, E.A.D. 2004. Response of testate amoebae (Protozoa) to $\mathrm{N}$ and $\mathrm{P}$ fertilization in an arctic wet sedge tundra. Arctic, Antarctic and Alpine Research, 36: 77-82.

Mitchell, E.A.D. \& A.J. Buttler. 1999. Ecology of testate amoebae (Protozoa: Rhizopoda) in Sphagnum peatlands in the Jura mountains, Switzerland and France. Ecoscience, 6: 565-576.

Mitchell, E.A.D., L. Bragazza \& R. Gerdol. 2004. Testate Amoebae (Protista) Communities in Hylocomium splendens (Hedw.) B.S.G. (Bryophyta): Relationships with Altitude, and Moss Elemental Chemistry. Protist, 155: 423-436.

Mitchell, E.A.D., D.J. Charman \& B.G. Warner. 2008. Testate amoebae analysis in ecological and paleoecological studies of wetlands: past, present and future. Biodivers. Conserv., 17: 2115-2137.

Ng, I.S.Y., C.M. Carr \& K. Cottenie. 2009. Hierarchical zooplankton metacommunities: distinguishing between high and limiting dispersal mechanisms. Hydrobiologia, 619: 133-143.

Ohtani, S. 1986. Epiphytic algae on mosses in the vicinity of Syowa station, Antarctica. Mem. Natl Inst. Polar Res., Spec. Issue, 44: 209-219.

Opelt, K., C. Berg, S. Schönmann, L. Eberl \& G. Berg. 2007. High specificity but contrasting biodiversity of Sphagnumassociated bacterial and plant communities in bog ecosystems independent of the geographical region. ISME Journal, 1: 502-516.

Opravilová, V. \& M. Hájek. 2006. The variation of testacean assemblages (Rhizopoda) along the complete base-richness gradient in fens: a case study from the Western Carpathians. Acta Protozool., 45: 191-204.

Økland, R.H. 1999. On the variation explained by ordination and constrained ordination axes. J. Veg. Sci., 10: 131-136.

Pärtel, M. 2002. Local plant diversity patterns and evolutionary history at the regional scale. Ecology, 83: 2361-2366.

Paulissen, M.P.C.P. P.J. van der Ven, A.J. Dees \& R. Bobbink, R. 2004. Differential effects of nitrate and ammonium on three fen bryophyte species in relation to pollutant nitrogen input. New Phytologist, 164: 451-458. 
Peres-Neto, P.R., P. Legendre, S. Dray \& D. Borcard. 2006. Variation partitioning of species data matrices: estimation and comparison of fractions. Ecology, 87: 2614-2625.

Poulíčková, A., M. Hájek \& K. Rybníček (Eds). 2005. Ecology and palaeoecology of spring fens in the western part of the Carpathians. Palacký University, Olomouc: 29-57.

Poulíčková, A., P. Hájková, P. Křenková \& M. Hájek 2004. Distribution of diatoms and bryophytes on linear transects through spring fens. Nova Hedwigia, 78: 411-424.

Rapant, S., K. Vrana \& D. Bodiš. 1996. Geochemical atlas of Slovakia. Part Groundwater. GSSR, Bratislava: $127 \mathrm{pp}$.

Ricci, C. 2001. Dormancy patterns in rotifers. Hydrobiologia, 446/447: 1-11

Round, F.E., R.M. Crawford \& D.G. Mann. 1990. The Diatoms. Biology and morphology of the genera. Cambridge University Press, Cambridge: 747 pp.

Rothfritz, H., I. Jüttner, A.M. Suren \& S.J. Ormerod. 1997. Epiphytic and epilithic diatom communities along environmental gradients in the Nepalese Himalaya: implications for the assessment of biodiversity and water quality. Arch. Hydrobiol., 138: 465-482.

Schröder, T. 2005. Diapause in monogonont rotifers. Hydrobiologia, 546: 291-306.

Segers, H. 1995. Rotifera 2: The Lecanidae (Monogononta). Guides to the Identification of the Microinvertebrates of the Continental Waters of the World. SPB Academic Publishing, The Hague: $226 \mathrm{pp}$.

Segers, H. \& W.H. De Smet. 2008. Diversity and endemism in Rotifera: a review, and Keratella Bory de St Vincent. Biodivers. Conserv., 17: 303-316.

Soininen, J. 2007. Environmental and spatial control of freshwater diatoms - a review. Diatom Res., 22: 473-490.

Strong, J. 1967. Ecology of terrestrial arthropods at Palmer Station, Antarctic Pininsula. In: J. L. Gressitt (Ed.), Ento- mology of Antarctica. American Geophysical Union, Washington D.C.: 357-371

Suren, A.M. 1992. Meiofaunal communities associated with bryophytes and gravels in shaded and unshaded alpine streams in New Zealand. New Zeal. J. Mar. Freshw., 26: $115-125$

Tahvanainen, T. 2004. Water chemistry of mires in relation to the poor-rich vegetation gradient and contrasting geochemical zones of northeastern Fennoscandian shield. Folia Geobot., 39: 353-369.

ter Braak, C.J.F. \& P. Šmilauer. 2000. CANOCO Reference manual and Canodraw for Windows user's guide. Software for canonical community ordination (ver 4.5). Biometris Wageningen: $266 \mathrm{pp}$.

Van de Vijver, B., A. Van Kerckvoorde \& L. Beyens. 2003. Freshwater and terrestrial moss diatom assemblages of the Cambridge Bay area, Victoria Island (Nunavut, Canada). Nova Hedwigia, 76: 225-243.

Vincke, S., B. Van der Vijver, N. Gremmen \& L. Beyens. 2006. The Moss Dwelling Testacean Fauna of the Strømness Bay (South Georgia). Acta Protozool., 45: 65-75.

Vitt, D.H. 2000. Peatlands: ecosystems dominated by bryophytes. In: A. J. Shaw \& B. Goffinet (Eds), Bryophyte biology. Cambridge University Press, Cambridge: 312-343

Wallace, R.L. \& W.T. Edmondson. 1986. Mechanism and adaptive significance of substrate selection by a sessile rotifers. Ecology, 67: 314-323.

Warner, B.G. 1990. Testate amoebae (Protozoa). In: B.G. Warner (Ed.), Methods in Quaternary Ecology Geoscience Canada. Ecological Association of Canada, St John's Newfoundland: 65-74.

Werum, M. \& H. Lange-Bertalot. 2004. Diatomeen in Quellen unter hydrogeologischen und antropogenen Einflüssen in Mitteleuropa und anderen Regionen. Iconographia Diatomologica, 13. Koeltz Scientific Books, Koenigstein: 417 pp. 